\title{
特集 水産業と外来生物
}

\section{外来種の生態リスク}

\author{
松田裕之, *加藤 団 \\ 横浜国立大学環境情報学府
}

Ecological risks of exotic species

\section{HIROYUKI MATSUDA AND DAN KATOH}

\begin{abstract}
Faculty of Environment and Information Sciences, Yokohama National University, Yokohama, Kanagawa 240-8501, Japan
\end{abstract}
\section{1. 生態系サービスとは}

環境経済学では, 生態系の経済価值を図る研究がいく つかある。「金で買えない価值がある」ことは社会常識 だが，それは承知の上で，何とか評価しようという試み は，政策決定の上で大きな影響を与えている。詳しくは 教科書 ${ }^{1)}$ にあるが，生態系が人間にもたらす福利への貢 献を，(1)物質循環等の基盤サービス，(2)燃料・食糧・水 等の供給サービス, (3)気象等の調節サービス, および(4) 精神的宗教的審美的価值をもたらす文化的サービスにわ けて議論する。 ${ }^{2)}$ 漁業による食料生産は(2)供給サービス に属する。Costanza et al. ${ }^{3)}$ はこれらを 17 項目に分けて 世界全体の生態系サービスと自然資産の経済価值を試算 した。その試算值の定量的評価については批判もあり, すべての価值を評価できているわけではないが，(2)供給 サービスがもたらす経済価値よりも，(1)基盤サービスの ほうがはるかに高く評価されている。この点は異論がな い。

たとえば, サンゴ礁, 干潟, 藻場を初めとする沿岸生 態系は, 単位面積当たりの経済価値では熱帯林に劣らぬ と評価されている。淿潟には内湾の海水を浄化する機 能がある。これを污水処理施設で代替すれば，その程度 の費用がかかると試算されている。

たとえば，中部国際空港など，沿岸自然環境を開発に よって損なう場合, 利害関係者としては漁業権を持つ地 元漁業者が主な交涉の対象となり, 補償額は漁業によっ て得られる利益から算定されているという。到しかし, 生態系サービス全体の経済価值のうち, 漁獲による供給 サービスがごく一部であるとすれば，漁業補償だけでは 損なわれた生態系の経済価值を補償できているとは言え ない。漁業自身が得る自然の恵みよりずっと豊かな生態 系の恵みがあって初めて持続可能な収益が可能になるも のと考えられる。

上記のように，漁業だけが海洋生態系から価値をもた
らすわけではない。しかし，逆はある程度成り立つだろ う。すなわち持続可能な漁業が成り立っているというこ とは，その海域の生態系機能が健全であることを示唆し ている。この仮説がぞこまで具体的に証明できるかは今 後の課題だが, 漁業の衰退と生態系機能の変化は検証可 能と期待する。

保全生態学では, 上位捕食者の存在や要（かなめ）種 （keystone 種）の存在を, 生態系の健全性（ここでは, もともとの生態系の構造と機能が損なわれていない状態 を意味する）の指標とすることがある。上位捕食者が生 息できるためには，食物連鎖の会にいる生態系機能があ る程度保持されていると期待される。それならば，「責 任ある漁業」そのものが生態系の健全性の指標々位置付 けられるだろう。上位捕食者に比べて，はるかに詳しい データがそろう。利用している魚種とその体長組成の変 化等が漁獲統計から利用できる。主たる漁場の移動もわ かる。漁業から得られたデータを分析すれば, 海洋生態 系の状態をある程度診断することができるだろう。その ためには, データが正確に公表されることが必要であ る。すなわち,「責任ある漁業」が健全な生態系の指標 となりえる。2005 年に世界自然遺産に登録された知床 では, 登録海域（距岸 $3 \mathrm{~km}$ ) で通常の漁業が営まれて いる。海域管理計画には 28 魚種（分類群）の羅臼・斜 里漁協の漁獲量の年次変化が記されている (Makino et $a l$. 未発表)。

\section{2. 人間活動が水圏生態系に及ぼす悪影響}

2002 年に改定された日本の生物多様性国家戦略に は, 生物多様性の喪失を招く「3つの危機」として, 3 つの危機として「人間活動に伴う負のインパクトによる 生物や生態系への影響」「人間活動の縮小や生活スタイ ルの変化に伴う影響」「移入種等の人間活動によって新 たに問題となっているインパクト」が挙げられている。 日本の里山は弥生時代から続く二次的自然であり, 燃料

* Tel : 81-45-339-4362. Fax : 81-45-339-4373. Email : matsuda@ynu.ac.jp 
革命まで薪炭林を利用し続けてきた。水田（特に中山間 地域の棚田）には湿地性の動植物が生息し，未利用の湿 地の多くが開発されたために, 水田が絶隇危惧種の宝庫 として保全上の価值を持つことになった。2004 年に制 定された特定外来生物法では海外から導入された外来種 に限っているが，本来は外来種の脅威には国内移入種も 含まれる。そして, 淡水生物では河川ごとに生息地が分 かれて抢り，種苗放流事業によって他の河川からの移入 が大きな問題となっている。したがって, 水産分野に打 いては, 国内移入種問題も重要な検討課題である。

生物多椂性には, 種内変異をもたらす遺伝的多様性, 種の多様性，それにさまざまな生態系が隣接する豊かな 景観の 3 つのレベルがある。種苗放流事業では, ごく わずかの親から育てた種苗を放流することがあり，その 場合には遺伝的多様性が損なわれ, さらに別の地域の遺 伝子をもつ魚を導入することがある。

里山と並んで里海という言葉があるが，これらは相違 点も多い。どちらも, 人為的影響を受けて生態系機能が 原生自然から変化し, 一部の生態系サービスを高めてい る場所と考えられる。しかし, 里山が上記のように生物 多様性の宝庫と位置付けられることがあるのに対し, 里 海にはそのような役割は少ない。

\section{3. 海域におけるバラスト水問題}

20 世紀に海外貿易が発達するとともに, 外来の微生 物と細菌が船舶によって非意図的に導入され, 世界各地 で赤潮など生態系破壊等の深刻な問題を引起した（図 1)。船舶は船体の安定のために海水を船体の専用タン クに封入し航行している。これがバラスト水である。こ のバラスト水への混入と船底への付着が, 微生物や細菌 の非意図的導入の主要因と考えられる。

2004 年 2 月 13 日に海洋環境保護委員会 (MEPC) に打いて船舶バラスト水中に含まれる動植物の排出低減 を目的とした「バラスト水管理のための国際条約(以降,

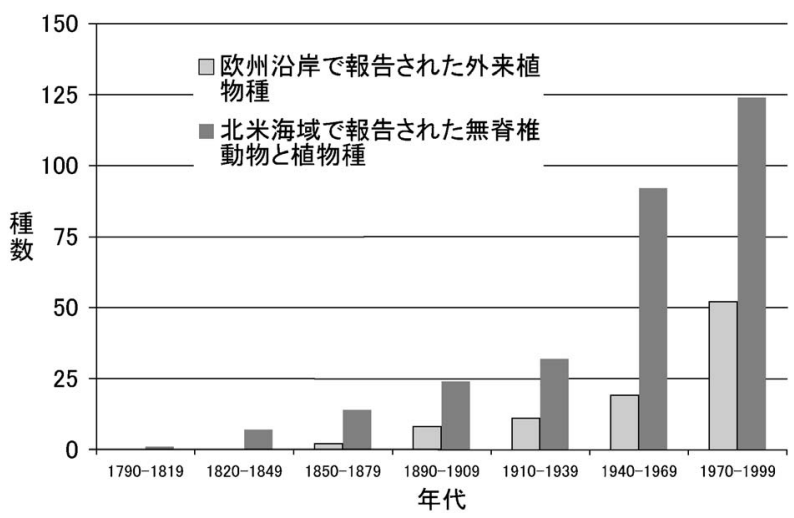

図 1 海洋の欧州沿岸で報告された侵入海洋植物と北米 で報告された海洋植物と無脊椎動物の新入手の数の年 次変化（ミレニアム生態系評価パネル 2005 より）
バラスト水管理条約)」が採択された（加藤・松田 未発 表)。この条約では, 船舶のバラスト水抢よび沈殿物を 通じ，有害な水生生物等の移動により生じる生態系への 影響を最小化し，船舶がバラスト水交換を行う場合には 表 1 の海域で交換を行い, 船舶がバラスト水を排出す る場合には, 含まれる水生生物の量を基準値（表 2）未 満とすることなどが定められた。しかし，特に短期間の 航海の場合, 海象・気象条件によっては表 1 に満たす バラスト水交換が事実上不可能な場合がある。したがっ て各船舶は表 2 に定める装置を備えなければならず, 技術的にも費用の面でも多くの困難をともなうことが予 想される。

加藤・松田 (未発表) は, 香港及び北米から日本に航 行したコンテナ運搬船よりバラスト水試料を採取し, 混 入した海洋微生物の排出基準値への適合可能性を評価し た。その結果, 浱水前に洋上でバラスト水の総入れ替え を行なった試料に関しては, 排水中の微生物個体数が極 めて低かった。また, 排水中の微生物量を左右する要因 は残椬に潜んでいる個体数であると考えられ, 残椬を調 查することでバラスト水による外来種侵入の詳細が明ら

表 1 海洋環境保護委員会 (MEPC)「バラスト水管理の ための国際条約」が定めたバラスト水交換海域 (加藤, 松田未発表を参照)

\begin{tabular}{lll}
\hline (1) 原 則 & $\begin{array}{l}\text { 陸岸から } 200 \text { 海里以上離れ } \\
\text { 水深 } 200 \mathrm{~m} \text { 以上の海域 }\end{array}$ \\
\hline $\begin{array}{ll}\text { (2) } \\
\text { (1)の海域で交換不可能な } \\
\text { 場合 }\end{array}$ & $\begin{array}{l}\text { 陸岸から } 50 \text { 海里以上離れ水 } \\
\text { 深 } 200 \mathrm{~m} \text { 以上の海域 }\end{array}$ \\
\hline
\end{tabular}

(3) (1), (2)の海域で交換不可 能な場合

寄港国が定めた交換海域

（船舶は，(1)，(2)の海域でバラスト水交換を行う場合，予定の航路 からの離脱, 迂回をする必要はない)

表 2 MEPC「バラスト水管理のための国際条約」が定め た装置による処理を行った場合の排出基準（加藤・松 田未発表を参照）

\begin{tabular}{|c|c|}
\hline 対象水生生物 & 備 考 \\
\hline \multicolumn{2}{|l|}{$50 \mu \mathrm{m}$ 以上の水生生物 } \\
\hline （主に動物性プランクトン） & \multirow{3}{*}{$\begin{array}{l}\text { 外洋の海水に含まれ } \\
\text { る水生生物より更に } \\
\text { 少ない基準 }\end{array}$} \\
\hline 10 個体 $/ \mathrm{m}^{3}$ 未満 & \\
\hline $\begin{array}{l}10 \sim 50 \mu \mathrm{m} \text { の水生生物 } \\
\text { (主に動物性プランクトン) }\end{array}$ & \\
\hline
\end{tabular}

10 個体 $/ \mathrm{mL}$ 未満

\begin{tabular}{lrl}
\hline 病原性コレラ & $1 \mathrm{cfu} / 100 \mathrm{~mL}$ 未満 & 日本の海水浴場の基 \\
大腸菌 & $250 \mathrm{cfu} / 100 \mathrm{~mL}$ 未満 & 準よりやや厳しい基 \\
腸球菌 & $250 \mathrm{cfu} / 100 \mathrm{~mL}$ 未満 & 準 \\
\hline
\end{tabular}

(cfu : 寒天培地基を用いてその平板上に検水を塗布し形成される群 体数) 
かになると期待される。

洋上交換（バラスト水の外洋航行中の交換）は外来種 問題への有効な対策のひとつであり, 多くの船舶で実施 されている。しかし, 外洋航行中のバラスト水交換は海 象・気象状況によっては危険を伴う。このため, バラス 卜排水前に水中の海洋微生物を処理する方法として, 物 理的処理，熱, 超音波, 紫外線, 銀イオン, 電気等), 機械的処理（メッシュによる濾過等）, 化学的処理（才 ゾン, 酸素除去, 塩素等) など, 様々な技術の研究開発 が進められているが，現時点ではどれも実用化していな い。

バラストタンク内は微生物が潜伏するのに適した構造 をした部分が多く，微生物はタンク内残渣に潜伏し長期 間の航海を経ても船外に生きて排出されることがあ る。 ${ }^{6}$ ) 加藤・松田（未発表）によると，体長 $10 \sim 50 \mu \mathrm{m}$ の微生物に関しては国際条約に定められた基準值の達成 は困難でない。しかし, 体長 $50 \mu \mathrm{m}$ 以上の微生物は, 基準予定值の数百倍以上存在しており，処理技術の開発 と実用化が必要である。

バラスト水からの微生物侵入リスクをゼロにはできな いとすれば，洋上交換を推奨し，海象気象条件によって は交換を免除する指針を設けるという選択肢も検討しう るだろう。この場合は海象により洋上交換をしないバラ ス卜水が海外から持ち込まれる。しかし，費用対効果は 高いかもしれない。

外来種の場合は, 本来は, 移入リスクを徹底してゼロ にするのが鉄則である。いったん移入定着した外来種を 根絶するのは膨大な労力が必要であり, 新たな侵入種を 水際で阻むほうが確実であり, 経済的である。上記のバ ラスト水管理条約もリスクゼロを目指しているように見 えるが，技術的に未熟であり，かつ，膨大な費用がかか る。実施できるならば防いだほうがよいが，作った条約 が実行されなければ，結局は生態系を守ることはできな い。重要なことはほぼ実行できる規則を作り, 確実に実 行させることである。その後の実施状況が注目される。

その他に, 船底などにフジッボなどが付着することで も外来種問題が生じる。付着生物は船の燃費にも影響す るため,これを除去するための船底塗料にトリブチルス ズ（TBT）が使われた。これは生物の付着を防ぐ意味 では効果的だったが, 沿岸の新腹足類を雄化させるなど 強い内分泌擋乱作用があり，1980 年ころから規制され 始めた。

\section{4. 環境にやさしい漁業とは}

日本の漁業を見ていると，いつも環境対策が後手に回 っているように見える。新たな環境問題が生じたとき に，常にそれを漁業への障害とみなしているように見え る。乱獲で激減した大型鯨類の保全のために設けられた 国際捕鯨委員会で生態系保護や倫理問題で捕鯨の全面禁
止が指摘されると, 環境問題を持続可能な漁業の障害物 ととらえるようになった。ワシントン条約で解類, ウミ ガメ類，ヨーロッパウナギなどの水産資源が規制される ことにも, ワシントン条約は水産資源になじまないとい う態度をとり続けている。マグロ類の国際資源管理につ いても, 大西洋 (ICCAT) やミナミマグロ (CCSBT) などの国際条約に比べて, 日本近海での取り組みは遅れ て始まった。アユなどの種苗放流事業による遺伝子污 染, サケ科魚類の餒化放流事業, トドや海獣類の駆除や 混獲の防止策, 海山などの底引きトロール漁業などにつ いて，環境保護運動を漁業に敵対するものとしてのみと らえ, 自ら「環境にやさしい漁業」への対応を積極的に とっているようには見えない。ウナギやサンマなど, 中 国や韓国が本格的に利用する前に国際条約を築き，日本 主導で国際管理すべき資源は, 生産, 消費両面での日本 の独占的地位が失われるまで, 何の対策もとっていない ように見える。

水産物も基本は自由貿易であり, 乱獲された水産物 も，管理された水産物も市場に出回れば区別がつきにく い。そのため, 国際的な環境団体は農林水産物の自由貿 易には批判的である。農林水産物の生産実態に一定の環 境基準を設けて，それを満たすものだけを輸入するよう にすれば，日本の漁業をある程度守ることができる。労 働賃金の格差は埋めようがないが，少なくとも，便宜置 籍船による乱獲や海岸生態系を破壊して作った養殖水産 物の輸入を制限することは可能だろう。

また，消費者が選択できるようにする「エコラベル」 も有効である。海外では海洋認証制度 (MSC) や海に やさしい水産食品（http://blueocean.org/seafood/) や 環境と健康によい水産食品（http://www.environmentaldefense.org/tool.cfm?tool=seafood）という紹介があ る。意外なことに, 養殖魚は必ずしも批判されていな い。日本でも, マグロ漁業では「責任あるまぐろ漁業推 進機構」(OPRT), 大日本水産会でも「マリン・エコラ ベル・ジャパン (Marine Eco-Label Japan, MEL ジャパ ン)」というエコラベルを提案した。

無条件で外国の水産物の輸入を規制することはできな いが，「環境にやさしい漁業」を守るという趣旨ならば， 世界の環境団体がこれを支持する。自動車の排ガス規制 などでも，1970 年に米国は極めて厳しい排出基準を 1976 年から課すマスキー法を成立させた。実際には米 国でなく，日本企業がこの基準を満たす車種を開発し， 実施前に廃案に追い込まれた。

最初に述べたと打り, 持続可能な漁業は豊かな生態系 の賜物である。海洋生態系の保全は持続可能な漁業を守 るために必要なことであり,「環境にやさしい漁業」か ら得られた水産物に輸入を制限することは, 自国の漁業 を他国で乱獲している漁業との過当競争から守ることに 
通じるはずである。そのためには, 国内漁業の環境基準 を上げる必要がある。それは, 海洋生態系を保全する上 でも効果的である。日本政府が持続可能な漁業とそのた めの環境保全措置を支援し, 持続不可能な漁業による水 産物の輸入を制限すること, すなわち,「環境にやさし い漁業」を育てることが, 日本漁業の未来を保障する唯 一の道である。

外来種問題も, 共通の枠組みでとらえることができ る。上記の自動車の排ガス規制と同じく，皆が従わねば ならない公正な規則であれば，それが厳しくても，産業 界は対応できる。日本はまだ世界一の水産物消費国であ る。日本が高い環境基準を作れば，世界はそれに従わざ るを得ない側面があるはずである。日本は海洋国家であ る。外来種の侵入を防ぐことは, 日本の生態系を守る上 で必要なことである。我々自身が，このような環境意識 を強く持つことが，持続可能な漁業を守る上でも重要で ある。

\section{文献}

1）日本生態学会編. 生態学入門. 東京化学同人. $2004 ; 1-$ 273.

2）国連ミレニアム生態系評価. 生態系サービスと人類の未 来. 横浜国立大学 21 世紀 COE 翻訳委員会訳. 2007; 1240 .

3) Costanza R, d'Arge R, de Groot R, Farber S, Grasso M, Hannon B, Limburg K, Naeem S, O’Neill RV, Paruelo J, Raskin RG, Sutton $\mathrm{P}$, van den Belt M. The value of the world's ecosystem services and natural capital. Nature 1997; 387: 253-260.

4) 松田裕之. ゼロからわかる生態学, 環境, 進化, 持続可能 性の科学. 共立出版. 2004; 1-245.

5）長崎孝俊. バラスト水問題への今後の対応. 日本海難防止 協会情報誌「海と安全」. 2004 年秋号. 2004; 24-27.

6) Smith LD, Wonham MJ, McCann LD, Ruiz GM, Hines $\mathrm{AH}$, Carlton JT. Invasion pressure to a ballast-flooded estuary and an assessment of inoculant survival. Biol. Invasi. 1999; 1: 67-68. 